Published in final edited form as:

Org Lett. 2016 September 16; 18(18): 4714-4717. doi:10.1021/acs.orglett.6b02359.

\title{
Lithium Hexamethyldisilazane Transformation of Transiently Protected 4-Aza/Benzimidazole Nitriles to Amidines and their Dimethyl Sulfoxide Mediated Imidazole Ring Formation
}

\author{
Reham A. I. Abou-Elkhair ${ }^{\dagger, \ddagger},{ }^{,}$, Abdalla E. A. Hassan ${ }^{\ddagger}$, David W. Boykin ${ }^{\dagger,}{ }^{,}$, and W. David \\ Wilson ${ }^{\dagger}$ \\ †Department of Chemistry, Georgia State University, Atlanta, Georgia 30303, United States \\ ${ }^{\ddagger}$ Applied Nucleic Acids Research Center \& Chemistry Department, Faculty of Sciences, Zagazig \\ University, Zagazig, Egypt
}

\begin{abstract}
Trimethylsilyl (TMS)-transient protection successfully allowed using Lithium hexamethyldisilazane (LHMDS) to prepare benzimidazole (BI) and 4-azabenzimidazole (azaBI) amidines from nitriles in 58-88\% yields. This strategy offers a much better choice to prepare BI/ azaBI amidines than the lengthy, low yielding Pinner reaction. Synthesis of aza/benzimidazole rings from aromatic diamines and aldehydes was affected in Dimethyl sulfoxide (DMSO) in 10-15 min, while known procedures require long time and purification. These methods are important for $\mathrm{BI} / \mathrm{azaBI}-$ based drug industry and for developing specific DNA binders for expanded therapeutic applications.
\end{abstract}

\section{Graphical abstract}

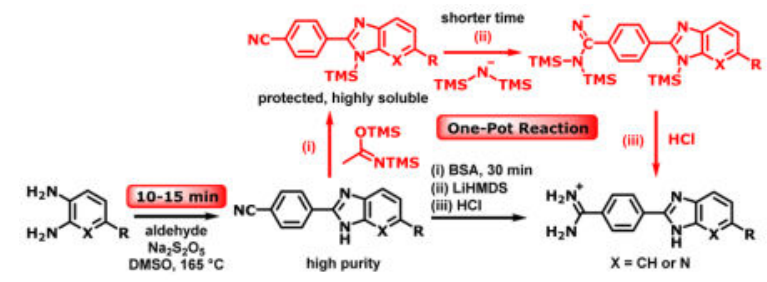

Benzimidazole (BI) constitutes an important scaffold found in over a dozen approved pharmaceuticals. ${ }^{1,2}$ Additional BI derivatives show potent antiplasmodial, ${ }^{3}$ antiinflammatory, ${ }^{4}$ antiviral ${ }^{5}$ and anticancer activities. ${ }^{6}$ Derivatives of the BI analogue, $4-$ azabenzimidazole (azaBI) have recently been studied in animal models and identified as potent anti-tumor, anti-inflammatory, ${ }^{7}$ and antidiabetic agents ${ }^{8}$ (Figure 1). Structures

\footnotetext{
“Corresponding Authors: rabouelkhair1@gsu.edu, riham31@yahoo.com (R. Abou-Elkhair), and dboykin@gsu.edu (D. Boykin). Notes

The authors declare no competing financial interest.

Supporting Information

The Supporting Information is available free of charge on the ACS Publications website.

Experimental procedures, characterization, ${ }^{1} \mathrm{H}$ and ${ }^{13} \mathrm{C}$ NMR spectra (PDF)
} 
containing the BI nucleus can also be used as light-up adenine thymine base pair (AT) specific DNA binders, ${ }^{9}$ and fluorescent probes in biological systems with potential for developing new biomarkers. ${ }^{10,11}$ Furthermore, rational design of azaBI-based DNA minor groove binders led to morphing traditional BI recognition of DNA from AT specific ${ }^{12-15}$ to guanine $(G)$-containing sequence specific (Figure 1) by introducing the aza group. ${ }^{16-18}$ This represents a key milestone showing that small molecules can be structured to recognize any given sequence on DNA. Targeting DNA at specific sequences augments a therapeutic strategy of controlling gene expression as a venue for treating many intractable diseases. ${ }^{19,20}$ DNA minor groove binders, typically, possess positively charged moieties for stronger interaction with the DNA backbone. Among known positively charged groups, amidines are appealing for their excellent cellular and nuclear uptake. ${ }^{12,21}$ Available methods to prepare amidino BI/azaBI and also to construct substituted BI/azaBI rings, in general, suffer from long reaction time and low efficiency.

Amidines are commonly prepared from nitriles by three methods: the Pinner reaction, ${ }^{22}$ amidoxime method, ${ }^{23}$ and nucleophilic addition of lithium hexamethyldisilazane ${ }^{24}$ (LHMDS). The latter approach is the most convenient, because it takes a single step to give the silylated amidines, which provides amidine salts upon $\mathrm{HCl}$ workup. It was also adapted to prepare $N$-substituted amidines ${ }^{25}$ related to earlier derivatives ${ }^{26}$ However, for BI and azaBI systems, LHMDS deprotonates the ring $\mathrm{NH}$, preventing the desired reaction due to a delocalized negative charge on the nitrile. Thus, amidines of such systems are usually prepared by one of the other two methods. ${ }^{27,28}$ The amidoxime method involves three steps, in which the nitrile is converted to the amidoxime, followed by acetylation to $O$ acetoxyamidoxime, and then hydrogenolysis to give the amidine. The drawbacks of this method are not only the multistep procedure but also the intermediates are frequently sparingly soluble, leaving the Pinner method, by default, more popular. The Pinner reaction involves two steps: the formation of imidate ester by the action of anhyd $\mathrm{HCl}$-saturated ethanol and conversion to the amidine by ammonia. Low solubility of BI/azaBI molecules leads to long reaction times with the Pinner method, where reactions requiring 3-10 days for each step are commonly encountered. ${ }^{29-32}$ More problematic is that imidate esters readily hydrolyze to amides, ${ }^{22}$ which is difficult to avoid during their isolation to remove excess $\mathrm{HCl}$. These facts result in poor yields, and failure of the reaction in some cases.

Herein, we report a novel strategy that allows using LHMDS with BI/azaBI nitriles to make amidines via transient protection of BI/azaBI ring NH in a one-pot procedure. Given the significance of $\mathrm{BI} / \mathrm{azaBI}$ structure in industry and as biologically active agents, we also present optimized conditions and suggest a mechanism for a facile formation of BI/azaBI rings from aldehydes and diamines in DMSO.

\section{Transient Protection Strategy}

The trimethylsilyl group (TMS) has extensively been used in nucleoside chemistry for the Silyl Hilbert-Johnson synthesis, ${ }^{33}$ and for transient protection of $3^{\prime}-\mathrm{OH}$ groups. ${ }^{34} \mathrm{We}$ employed $N, O$-bis(trimethylsilyl)acetamide (BSA) as a mild and efficient reagent ${ }^{35}$ to transiently protect $\mathrm{BI}$ and azaBI ring NH groups with TMS. Thus, suspensions of the azaBI nitrile derivatives 1a-c in THF were treated with BSA for $0.5 \mathrm{~h}$ at $\mathrm{rt}$ (Scheme 1). The 
silylation was visually indicated by the homogeneity of the mixture within 5-10 min. Subsequent addition of excess LHMDS led to the consumption of the silylated BI/azaBI nitrile intermediates in 4-6 h. On the other hand, our initial attempts to perform the reaction on Boc-protected 1a resulted in deprotonation of the 5-methyl group as indicated by the maroon color, and cleavage of the Boc group, and failure of the reaction. Thus, it is clear that the methyl on TMS-protected 1a is stable. It is also worth noting that TMSintermediates enabled highly concentrated reaction solutions, leading to shorter reaction time. In contrast, the reaction of nitriles of Boc-protected indoles, as a suspension in THF, with LHMDS required up to 3 days. ${ }^{27}$ This demonstrates that our strategy is successful and efficient.

Quenching the reaction with enough $\mathrm{HCl}$ to cause desilylation, normally, produces large amounts of $\mathrm{NH}_{4} \mathrm{Cl}$ due to reaction with excess LHMDS. To avoid this, we first quenched with a stoichiometric amount of an acid to convert LHMDS to hexamethyldisilazane (HMDS), which was removed by evaporation. $\mathrm{EtOH}-\mathrm{HCl}$ was then added to give the amidine salts and remove the TMS transient protection. The salts were precipitated by ether and mixed with water at $\mathrm{pH}>9$ to give the free bases and to remove inorganic salts. Conversion to the $\mathrm{HCl}$ salts and precipitation again gave $\mathbf{2 a - c}$. The resulting amidines were obtained in high yields (85-88\%, Scheme 1$)$ and were pure as judged by NMR and elemental analysese. This is highly remarkable because amidines prepared by other methods often require purification by crystallization, ${ }^{36}$ and chromatography on preparative HPLC, ${ }^{37,38}$ normal $^{36}$ or $\mathrm{C}_{18}$ reversed phase ${ }^{38}$ silica gel.

We made 2a by the amidoxime method in a total yield of $21 \%$ (Scheme S1, supporting information), showing that the one-pot LHMDS method is much more efficient in terms of the yield and reaction time.

\section{DMSO-Mediated Cyclization}

As mentioned above, we desired to optimize reaction conditions for efficient construction of substituted BI/azaBI rings. There are numerous conditions starting from aromatic aldehydes and $o$-phenylenediamine or 2,3-diaminopyridine to make the BI and azaBI, respectively, through an oxidative cyclization. Indeed, a 2012 review by Panda et al. listed 118 different conditions for this synthesis. ${ }^{39}$ The first step in this cyclization is the formation of the imine, followed by the cyclic aminal, which is then oxidized to the imidazole ring. We examined the most common conditions to make 1a. Reaction in DMF in presence of $\mathrm{Na}_{2} \mathrm{~S}_{2} \mathrm{O}_{5}$ or Na$\mathrm{HSO}_{3}{ }^{40}$ at 120 or $165{ }^{\circ} \mathrm{C}$ took $48 \mathrm{~h}$ and produced side products which mandated lengthy purification. A recent method stirring the reactants in hot $\mathrm{DMF} / \mathrm{H}_{2} \mathrm{O}(9: 1)^{41}$ gave incomplete reaction.

We speculated that catalyzing the oxidation would facilitate the cyclization. Using $p$ benzoquinone as an oxidant, ${ }^{39}$ scandium triflate ${ }^{42}$ or ferric chloride ${ }^{43}$ as recyclable oxidants did not improve reaction time or yield of 1a. Although, DMSO is a known oxidant, ${ }^{44}$ it does not appear to have been explored in this type of synthesis. Thus, we aimed to investigate the effect of DMSO in comparison to DMF for the synthesis of 1a (entry1, Table 1). Performing the reaction in DMSO under the same conditions, surprisingly, resulted in a complete 
reaction in only 15 min (entry 2). Most importantly, the product was easily recovered by adding water, and filtering the resulting precipitate, where no further purification was required as indicated by ${ }^{1} \mathrm{H}$ NMR. The cyclization of more derivatives (1b-1f) under the same conditions was finished in 10-15 min, giving excellent yields of 92-99\% (Scheme 2).In order to evaluate the role of DMSO, we ran the reaction in the absence of $\mathrm{Na}_{2} \mathrm{~S}_{2} \mathrm{O}_{5}$ and air (entries 3 and 4). The results indicated that both DMSO and $\mathrm{Na}_{2} \mathrm{~S}_{2} \mathrm{O}_{5}$ are crucial. The reactants were freely soluble in both DMF and DMSO; hence the role of DMSO was beyond solvation. ${ }^{45}$ Thus, we propose the mechanism shown in Scheme 3, suggesting that DMSO reacts with bisulfite to form an activated intermediate that takes part in the oxidation. This hypothesis is supported by related formation of an activated DMSO in the Swern, MoffattPfitzner and Parikh-Doering oxidations of alcohols. ${ }^{44,46}$

\section{Application on More Complex Molecules}

We tested our transient protection strategy for amidine synthesis on more complex BI/azaBI structures of six different amidines, which were designed as minor groove binders for specific recognition of DNA sequences. The synthesis of amide-containing mono- and diamidino derivatives, 7-9 is shown in Scheme 4. 1d was hydrolyzed to give acid $\mathbf{3}$, which was coupled with both 4-aminobenzamide and 4-aminobenzonitrile to give the azaBI mononitrile derivative containing two amide groups (4), and the dinitrile with one amide (6), respectively. Similarly, 1e was reacted to give the BI mononitrile derivative (5) with one amide group. While transiently protecting 4-6 for the one-pot preparation of amidines 7-9, BSA was also expected to silylate the amide groups. ${ }^{35,47}$ Hence, a molar ratio of BSA was used to fully silylate all the NH's. The amidines, 7-9 were obtained in good yields (Scheme 4) and high purity.

Schemes 5 and 6 represent the preparation of the monoamidine 11, and the symmetric diamidines 17 and 18. 4-(Hydroxymethyl)benzamide ${ }^{48}$ was coupled with 2-amino-6chloro-3-nitropyridine in presence of $t$ - $\mathrm{BuOK}^{49}$ to form the nitro derivatives, $\mathbf{1 0}$, which was reduced to the diamine and immediately used in the DMSO-mediated cyclization described above to give mononitrile $\mathbf{1 1}$ (Scheme 5). The dinitirile intermediates 15 and $\mathbf{1 6}$ (Scheme 6) were prepared in a similar fashion. The one-pot amidine synthesis gave 12, 17 and 18 (Schemes 5 and 6). All the nitrile intermediates of Schemes 4-6 were highly soluble upon TMS protection. The cyclization reactions for $\mathbf{1 1}, \mathbf{1 5}$ and $\mathbf{1 6}$ were again finished in $15 \mathrm{~min}$, but crystallization was required to afford pure azaBI products in yields of $61-65 \%$.

In conclusion, transient protection with TMS using BSA is a convenient and efficient strategy, which allowed the use of LHMDS to make BI and azaBI amidines from nitriles in a one-pot procedure. This strategy is advantageous in two ways: (1) it renders the nitrile intermediates highly soluble in THF leading to shorter reaction times, (2) it results in pure products, avoiding the need for extensive purification. This method is applicable on amide containing nitriles, and is a much needed alternative for the Pinner Reaction. The amidines prepared by our new strategy were obtained in high yields of up to $88 \%$. The transient protection should work in general where active $\mathrm{OH} / \mathrm{NH}$ protons obstruct the LHMDS reaction ${ }^{35}$ and the strategy is applicable for a wide range of cases where strong bases are used or increased solubility is needed to enhance the kinetics of a reaction. 
The synthesis of the $\mathrm{BI}$ and azaBI imidazole rings from the aldehyde and diamine in presence of metabisulfite has been optimized by using DMSO as a solvent. This condition led to significantly shorter reaction time than known conditions, where reactions were finished in only 10-15 min. The products were highly pure in most cases. Activated DMSO oxidation, presumably, plays an essential role in facilitating the imidazole ring formation.

These methods present significant advances, important for the facile synthesis of BI/azaBI derivatives industrially, for new drug synthesis, and for the design of ligands with specific binding and recognition of DNA bases.

\section{Supplementary Material}

Refer to Web version on PubMed Central for supplementary material.

\section{Acknowledgments}

We thank Dr. Moses Lee of Georgia State University for advice on the synthesis of methyl 6-amino-5nitropicolinate. This work was supported in the United States by the National Institute of Health [GM111749 to W.D.W and D.W.B].

\section{References}

1. Bansal Y, Silakari O. Biorg Med Chem. 2012; 20:6208.

2. Vitaku E, Smith DT, Njardarson JT. J Med Chem. 2014; 57:10257. [PubMed: 25255204]

3. Ferreira RS, Dessoy MA, Pauli I, Souza ML, Krogh R, Sales AIL, Oliva G, Dias LC, Andricopulo AD. J Med Chem. 2014; 57:2380. [PubMed: 24533839]

4. Gaba M, Singh S, Mohan C. Eur J Med Chem. 2014; 76:494. [PubMed: 24602792]

5. LaPlante SR, Boes M, Brochu C, Chabot C, Coulombe R, Gillard JR, Jakalian A, Poirier M, Rancourt J, Stammers T, Thavonekham B, Beaulieu PL, Kukolj G, Tsantrizos YS. J Med Chem. 2014; 57:1845. [PubMed: 24159919]

6. Garuti L, Roberti M, Bottegoni G. Curr Med Chem. 2014; 21:2284. [PubMed: 24533813]

7. Vasbinder MM, Alimzhanov M, Augustin M, Bebernitz G, Bell K, Chuaqui C, Deegan T, Ferguson AD, Goodwin K, Huszar D, Kawatkar A, Kawatkar S, Read J, Shi J, Steinbacher S, Steuber H, Su Q, Toader D, Wang H, Woessner R, Wu A, Ye M, Zinda M. Bioorg Med Chem Lett. 2016; 26:60. [PubMed: 26614408]

8. Kim KM, Lee KS, Lee GY, Jin H, Durrance ES, Park HS, Choi SH, Park KS, Kim YB, Jang HC, Lim S. Mol Cell Endocrinol. 2015; 409:1. [PubMed: 25802191]

9. Dumat B, Bordeau G, Faurel-Paul E, Mahuteau-Betzer F, Saettel N, Metge G, Fiorini-Debuisschert C, Charra F, Teulade-Fichou MP. J Am Chem Soc. 2013; 135:12697. [PubMed: 23914799]

10. Kim HJ, Heo CH, Kim HM. J Am Chem Soc. 2013; 135:17969. [PubMed: 24237203]

11. Zhang N, Tian X, Zheng J, Zhang X, Zhu W, Tian Y, Zhu Q, Zhou H. Dyes Pigm. 2016; 124:174.

12. Munde M, Wang S, Kumar A, Stephens CE, Farahat AA, Boykin DW, Wilson WD, Poon GMK. Nucleic Acids Res. 2014; 42:1379. [PubMed: 24157839]

13. Liu Y, Kumar A, Depauw S, Nhili R, David-Cordonnier MH, Lee MP, Ismail MA, Farahat AA, Say M, Chackal-Catoen S, Batista-Parra A, Neidle S, Boykin DW, Wilson WD. J Am Chem Soc. 2011; 133:10171. [PubMed: 21627167]

14. Rahimian M, Kumar A, Say M, Bakunov SA, Boykin DW, Tidwell RR, Wilson WD. Biochemistry. 2009; 48:1573. [PubMed: 19173620]

15. Fairley TA, Tidwell RR, Donkor I, Naiman NA, Ohemeng KA, Lombardy RJ, Bentley JA, Cory M. J Med Chem. 1993; 36:1746. [PubMed: 8510102]

16. Harika NK, Paul A, Stroeva E, Chai Y, Boykin DW, Germann MW, Wilson WD. Nucleic Acids Res. 2016; 44:4519. [PubMed: 27131382] 
17. Paul A, Chai Y, Boykin DW, Wilson WD. Biochemistry. 2015; 54:577. [PubMed: 25495885]

18. Chai Y, Paul A, Rettig M, Wilson WD, Boykin DW. J Org Chem. 2014; 79:852. [PubMed: 24422528]

19. Darnell JE. Nat Rev Cancer. 2002; 2:740. [PubMed: 12360277]

20. Koehler AN. Curr Opin Chem Biol. 2010; 14:331. [PubMed: 20395165]

21. Wilson WD, Tanious FA, Mathis A, Tevis D, Hall JE, Boykin DW. Biochimie. 2008; 90:999. [PubMed: 18343228]

22. Dox, AW., Whitmore, FC. Acetamidine Hydrochloride. In: Blatt, AH., editor. Organic Syntheses. 2. Vol. 1. John Wiley and Sons; New York: 1941. p. 5

23. Judkins BD, Allen DG, Cook TA, Evans B, Sardharwala TE. Synth Commun. 1996; 26:4351.

24. Thurkauf A, Hutchison A, Peterson J, Cornfield L, Meade R, Huston K, Harris K, Ross PC, Gerber K, Ramabhadran TV. J Med Chem. 1995; 38:2251. [PubMed: 7783157]

25. Khalifa MM, Bodner MJ, Berglund JA, Haley MM. Tetrahedron Lett. 2015; 56:4109. [PubMed: 26097266]

26. Zhang Y, DeKorver KA, Lohse AG, Zhang YS, Huang J, Hsung RP. Org Lett. 2009; 11:899. [PubMed: 19199763]

27. Laughlin S, Wang S, Kumar A, Farahat AA, Boykin DW, Wilson WD. Chem - Eur J. 2015; 21:5528. [PubMed: 25703690]

28. Ismail MA, Batista-Parra A, Miao Y, Wilson WD, Wenzler T, Brun R, Boykin DW. Bioorg Med Chem. 2005; 13:6718. [PubMed: 16099661]

29. Berger O, Kaniti A, van Ba CT, Vial H, Ward SA, Biagini GA, Bray PG, O’Neill PM. ChemMedChem. 2011; 6:2094. [PubMed: 21905228]

30. Chackal-Catoen S, Miao Y, Wilson WD, Wenzler T, Brun R, Boykin DW. Bioorg Med Chem. 2006; 14:7434. [PubMed: 16889966]

31. Chaires JB, Ren J, Hamelberg D, Kumar A, Pandya V, Boykin DW, Wilson WD. J Med Chem. 2004; 47:5729. [PubMed: 15509172]

32. Farahat AA, Paliakov E, Kumar A, Barghash AEM, Goda FE, Eisa HM, Wenzler T, Brun R, Liu Y, Wilson WD, Boykin DW. Bioorg Med Chem. 2011; 19:2156. [PubMed: 21421317]

33. Vorbrüggen, H., Ruh-Pohlenz, C. Organic Reactions. John Wiley \& Sons, Inc; 2004. Synthesis Of Nucleosides.

34. Ti GS, Gaffney BL, Jones RA. J Am Chem Soc. 1982; 104:1316.

35. Klebe JF, Finkbeiner H, White DM. J Am Chem Soc. 1966; 88:3390.

36. Goker H, Ozden S, Yildiz S, Boykin DW. Eur J Med Chem. 2005; 40:1062. [PubMed: 15992965]

37. Wendt MD, Rockway TW, Geyer A, McClellan W, Weitzberg M, Zhao X, Mantei R, Nienaber VL, Stewart K, Klinghofer V, Giranda VL. J Med Chem. 2004; 47:303. [PubMed: 14711304]

38. Bakunova SM, Bakunov SA, Wenzler T, Barszcz T, Werbovetz KA, Brun R, Tidwell RR. J Med Chem. 2009; 52:4657. [PubMed: 19606902]

39. Panda SS, Malik R, Jain SC. Curr Org Chem. 2012; 16:1905.

40. Alp M, Goker H, Brun R, Yildiz S. Eur J Med Chem. 2009; 44:2002. [PubMed: 19010569]

41. Lee YS, Cho YH, Lee S, Bin JK, Yang J, Chae G, Cheon CH. Tetrahedron. 2015; 71:532.

42. Itoh T, Nagata K, Ishikawa H, Ohsawa A. Heterocycles. 2004; 63:2769.

43. Singh MP, Sasmal S, Lu W, Chatterjee MN. Synthesis. 2000:1380.

44. Tidwell TT. Synthesis. 1990:857.

45. We thank a reviewer for suggesting evaluation of the importance of DMSO's solvation role in the enhanced cyclization reaction. We tested this using $o$-phenylenediamine and 4-cyanobenzaldehyde in DMF in the presence of 1.1 and 2.0 equivalents of DMSO, under the same conditions. $70 \%$ conversion of the starting material was observed with 1.1 equivalents of DMSO, while $100 \%$ conversion was attained using 2.0 equivalents as detected by proton NMR.

46. Wu XF, Natte K. Adv Synth Catal. 2016; 358:336.

47. Li NS, Piccirilli JA. Chem Commun. 2012; 48:8754.

48. Kita Y, Nishii Y, Onoue A, Mashima K. Adv Synth Catal. 2013; 355:3391.

Org Lett. Author manuscript; available in PMC 2018 January 10. 
49. Tasker SZ, Bosscher MA, Shandro CA, Lanni EL, Ryu KA, Snapper GS, Utter JM, Ellsworth BA, Anderson CE. J Org Chem. 2012; 77:8220. [PubMed: 22928642] 


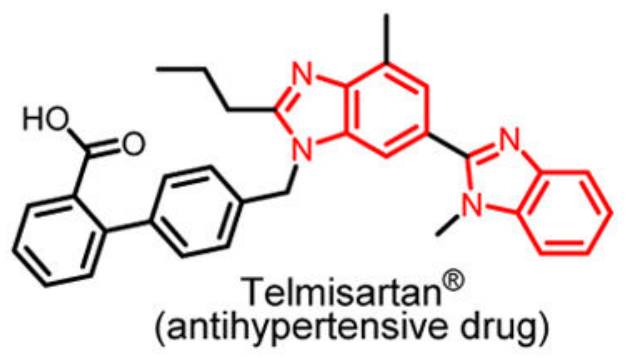<smiles>Cc1ccncc1NC(=O)c1cnc2[nH]c(-c3ccc(F)cc3)nc2c1</smiles>

Antidiabetic drug candidate<smiles>NC(=[NH2+])c1ccc(COc2ccc3nc(-c4ccc(C(=[NH2+])[NH3+])cc4)[nH]c3n2)cc1</smiles>

Figure 1.

Representative, biologically active BI/azaBI structures. 


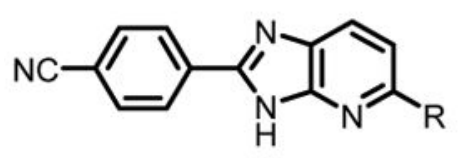

1a: $\mathrm{R}=\mathrm{CH}_{3}$

1b: $\mathrm{R}=\mathrm{OCH}_{3}$

1c: $\mathrm{R}=\mathrm{Cl}$

Scheme 1.

One-pot Synthesis of Simple azaBI Amidines
1- BSA, THF, $0.5 \mathrm{~h}$

$\stackrel{\text { 2- LiHMDS, rt, 4-6 h }}{\longrightarrow}$

3- $\mathrm{EtOH}-\mathrm{HCl}$

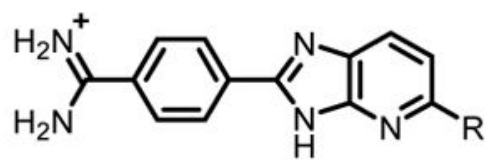

2a: $\mathrm{R}=\mathrm{CH}_{3}, 87 \%$

2b: $\mathbf{R}=\mathrm{OCH}_{3}, 88 \%$

2c: $\mathrm{R}=\mathrm{Cl}, 85 \%$ 
<smiles>[R]c1[X]c(N)c(N)cc1</smiles>

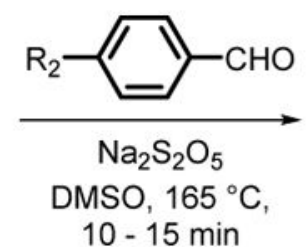

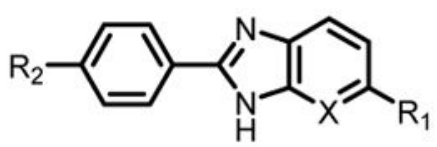

1a: $R_{1}=\mathrm{CH}_{3}, \mathrm{R}_{2}=\mathrm{CN}, \mathrm{X}=\mathrm{N}, 97 \%$

1b: $R_{1}=\mathrm{OCH}_{3}, \mathrm{R}_{2}=\mathrm{CN}, \mathrm{X}=\mathrm{N}, 92 \%$

1c: $R_{1}=\mathrm{Cl}, \mathrm{R}_{2}=\mathrm{CN}, \mathrm{X}=\mathrm{N}, 99 \%$

1d: $R_{1}=\mathrm{COOCH}_{3}, \mathrm{R}_{2}=\mathrm{CN}, \mathrm{X}=\mathrm{N}, 96 \%$

1e: $R_{1}=\mathrm{COOH}, \mathrm{R}_{2}=\mathrm{CN}, \mathrm{X}=\mathrm{CH}, 97 \%$

1f: $R_{1}=\mathrm{COOCH}_{3}, \mathrm{R}_{2}=\mathrm{OCH}_{3}, \mathrm{X}=\mathrm{N}, 94 \%$

Scheme 2.

Efficient Cyclization of BI and azaBI Rings 


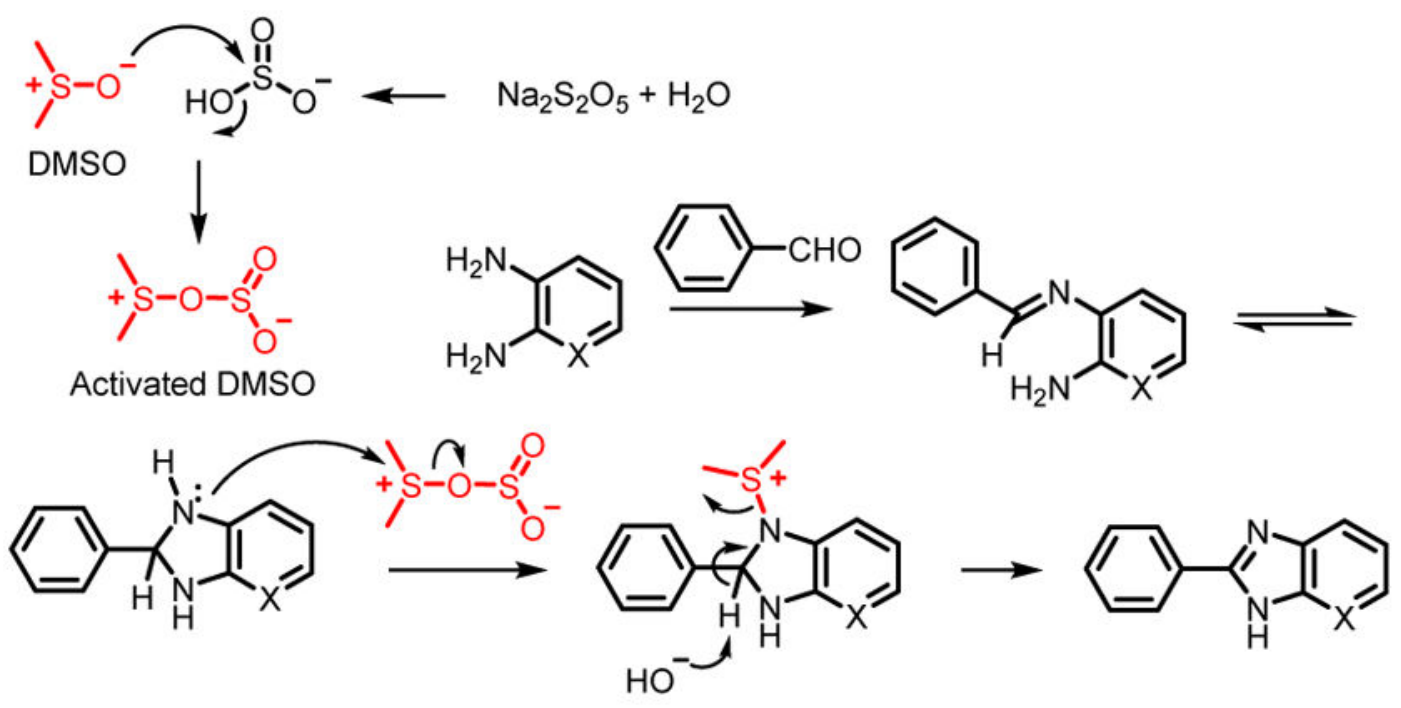

Scheme 3.

Plausible Mechanism for DMSO Reaction 

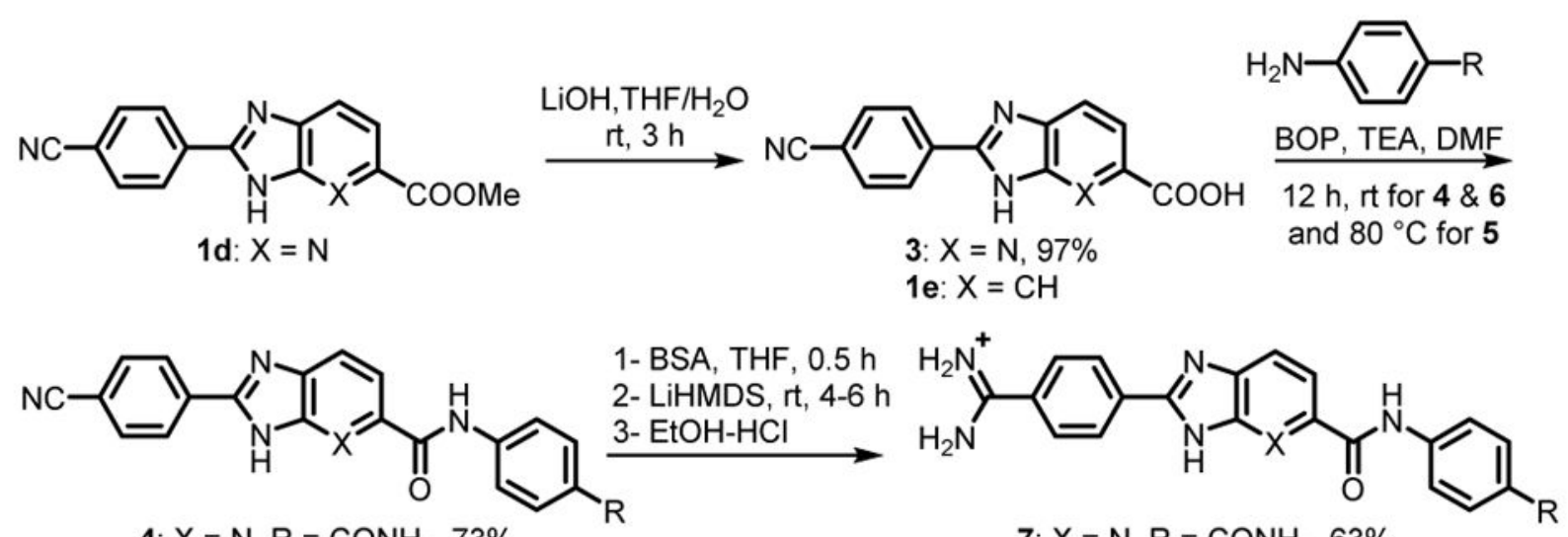

4: $\mathrm{X}=\mathrm{N}, \mathrm{R}=\mathrm{CONH}_{2}, 73 \%$

7: $\mathrm{X}=\mathrm{N}, \mathrm{R}=\mathrm{CONH}_{2}, 63 \%$

5: $\mathrm{X}=\mathrm{CH}, \mathrm{R}=\mathrm{CONH}_{2}, 66 \%$

8: $\mathrm{X}=\mathrm{CH}, \mathrm{R}=\mathrm{CONH}_{2}, 60 \%$

6: $X=N, R=C N, 83 \%$

9: $\mathrm{X}=\mathrm{N}, \mathrm{R}=\mathrm{C}\left(\mathrm{NH}_{2}\right) \mathrm{NH}_{2}{ }^{+}, 70 \%$

Scheme 4.

Synthesis of Amidino-BI/azaBI carrying Amides 


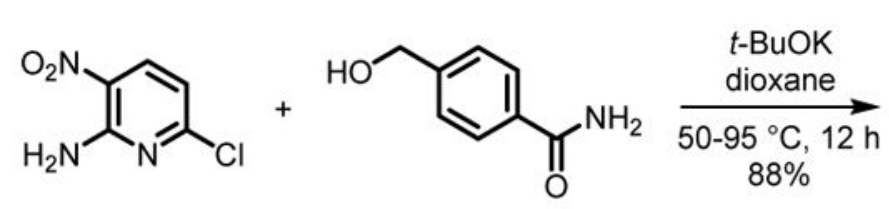

1- Ra-Ni, $\mathrm{H}_{2}, 45 \mathrm{psi}, 48 \mathrm{~h}$

2- 4-formylbenzonitrile $\mathrm{Na}_{2} \mathrm{~S}_{2} \mathrm{O}_{5}$ DMSO, $165^{\circ} \mathrm{C}, 15 \mathrm{~min}$ $64 \%$<smiles>NC(=[NH2+])c1ccc(-c2nc3ccc(OCc4ccc(C(N)=O)cc4)nc3[nH]2)cc1</smiles>

Scheme 5 .

Synthesis of Amidino-azaBI Carrying Benzyl Ether and Amide

11<smiles>NC(=O)c1ccc(COc2ccc([N+](=O)[O-])c(N)n2)cc1</smiles>

1- BSA, THF, $0.5 \mathrm{~h}$ 2- LiHMDS, rt, 4-6 h

$58 \%$ 
<smiles>[Y]COc1ccc([N+](=O)[O-])c(N)n1</smiles>

13: $\mathrm{X}=\mathrm{CH}_{2}, 38 \%$

1- Catalytic hydrogenation

2- 4-formylbenzonitrile $\mathrm{Na}_{2} \mathrm{~S}_{2} \mathrm{O}_{5}$

DMSO, $165^{\circ} \mathrm{C}, 15 \mathrm{~min}$<smiles>[R]c1ccc(C(C)=N)cc1</smiles>

1- BSA, THF, $0.5 \mathrm{~h}$

15: $\mathrm{X}=\mathrm{CH}_{2}, \mathrm{R}=\mathrm{CN}, 65 \%$

14: $X=p$-phenylene, $69 \%$

2- LiHMDS, rt, 4-6 h

3- $\mathrm{EtOH}-\mathrm{HCl}$

16: $\mathrm{X}=p$-phenylene, $\mathrm{R}=\mathrm{CN}, 61 \%$

17: $X=\mathrm{CH}_{2}, \mathrm{R}=\mathrm{C}\left(\mathrm{NH}_{2}\right) \mathrm{NH}_{2}{ }^{+}, 82 \%$

18: $\mathrm{X}=p^{-}$phenylene, $\mathrm{R}=\mathrm{C}\left(\mathrm{NH}_{2}\right) \mathrm{NH}_{2}{ }^{+}, 76 \%$

Scheme 6.

Synthesis of Diamidino-azaBI Carrying Ether and Benzyl Ether Linkages 


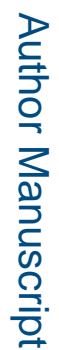
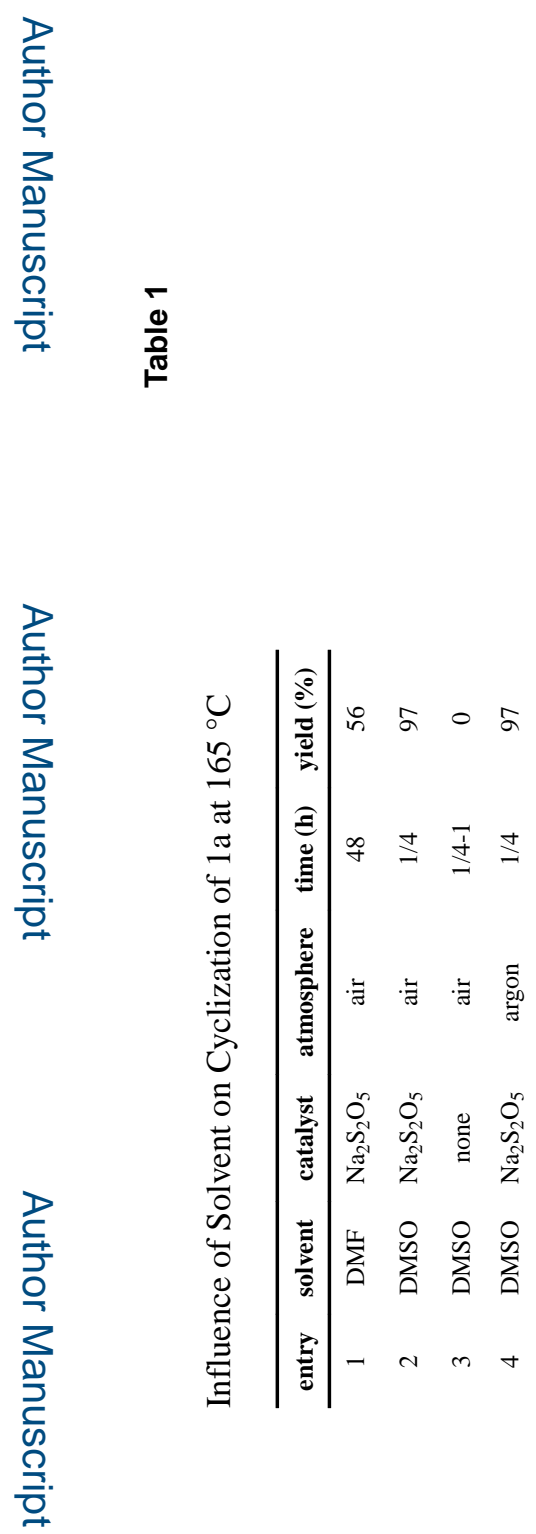

Org Lett. Author manuscript; available in PMC 2018 January 10. 